\title{
Public archaeology and political dynamics in Portugal
}

\author{
A reply to Bednarik
}

\author{
João Zilhão
}

Since the Côa affair, in 1995, hardly a month has passed without some vitriolic attack on my person, my work or on Portuguese archaeology in general appearing somewhere in a journal, a newsletter or a website corporate-owned by Bednarik or by his International Federation of Rock Art Organizations (IFRAO) associates. Given their academic and scientific irrelevance, I have never responded before. I do so now for the first time because, to my knowledge, this is also the first time that this kind of writing has been submitted to an independent peer-reviewed journal such as Public Archaeology.

In this string of attacks, I have been variously accused, among other things, of systematic professional vandalism (Jaffe, 1996), of deliberate destruction of the scientific evidence that would prove me wrong (Bednarik, 1996) and of being the undertaker of the Guadiana rock art (http:// mc2.vicnet.net.au/users/guadiana/). I have made myself available in the past to any kind of investigation of these charges by any recognized international association of professional archaeologists (such as the World Archaeological Congress (WAC) or the European Association of Archaeologists (EAA)) or by any recognized international organization devoted to heritage protection (such as the International Council on Monuments and Sites (ICOMOS) or the International Centre for the Study of the Preservation and Restoration of Cultural Properties (ICCROM)). That no such investigation has taken place, in spite of the seriousness of the charges (all the more so since they relate to a period during which I held the highest administrative responsibilities for the Côa rock art and Portuguese archaeology as a whole), is in itself an indicator of the credibility of the accusers.

Under the guise of a review of recent developments in Portuguese public archaeology, Bednarik's paper is simply another episode in his personal campaign against Portugal and myself (in fact, a significant percentage of the paper is simply the ipsis verbis reproduction of his IFRAO report no. 29 (Bednarik, 2002)). I am well aware that those unacquainted with the situation will find it hard to believe that this is the real motivation of a person who likes to present himself as God's Gift to Rock Art. That is why, to begin my response, I have to expose the fabricated nature of Bednarik's narrative and his ignorance of the reality he proposes to discuss.

By necessity, the initial section of my response follows the format of statement-counterstatement. Bednarik's statements are numbereed, followed by my comments or corrections, which also provide the factual base through which, at the end, I suggest an explanation for Bednarik's behaviour and offer my own overview of the broader significance of recent developments in Portuguese public archaeology. Given the limited space available here, this overview is brief, but I remain at the disposal of the editor of Public Archaeology to provide a more extended review, should that be considered of interest to the journal's readership.

\section{ON THE SITUATION OF PORTUGUESE ARCHAEOLOGY AND ROCK ART BEFORE 1995}

1. Until late 1995 ... Rock art was of such low priority that the destruction of countless sites was routinely approved by the state.

I know of no instance where the destruction of rock art was approved by the Portuguese state. I challenge Bednarik to give a single concrete example and to provide the documentation proving that the Portuguese state approved (not accepted, or ignored, or neglected to effectively protect, but actually approved) an act of rock art destruction.

2. The most severe destruction was usually caused by the construction of dams, the most devastating cases being those of the Fratel dam in the Tagus valley in the 1970s ... and the Pocinho dam in the Douro valley in the 1980 s.

Some $80 \%$ of the c. 40,000 petroglyphs inventoried at Fratel have indeed been submerged since the early 1970s. Before submersion, however, they were entirely recorded and, in 
this case, submersion did not entail any destruction. The petroglyphs are covered by shallow waters and are regularly exposed when the dam reservoir is emptied. In 1995, at the height of the Côa controversy, it was possible to inspect and film many panels (broadcast by the Portuguese TV station SIC); after more than 20 years of submersion, the petroglyphs were intact and undamaged.

In 1983, an ensemble of 23 rock surfaces decorated with fine-line engravings of the Iron Age (Baptista, 1983) was submerged at the site of Vale da Casa, in the upper Douro, by the Pocinho dam. Their current condition is unknown because of the depth of the reservoir at that point.

There have been speculations that a few scattered rock art panels may have been submerged by two dams built before the Tagus valley art was discovered: the Pracana dam, in the Ocreza, a tributary of the Tagus upriver from Fratel; and the Castelo de Bode dam, on the Zêzere, a subtributary of the Tagus downriver from Fratel. However, no secure evidence to that effect exists.

Fratel and Pocinho are the only documented instances of dams built in Portugal before 1995 that inundated areas with rock art. Fratel is the largest rock art ensemble in the Iberian Peninsula, and the loss of visibility and access caused by inundation is extremely significant in both scientific and heritage management terms. But, in conservation terms, the site is not destroyed; instead, it is well preserved.

3. The number of sites that fell victim to this form of 'site management' can only be conjectured, but it is certainly substantial and is at least in the hundreds. As a consequence, a large part of the country's rock art has been allowed, by the state-appointed protectors of this irreplaceable heritage, to be destroyed.

The number of rock art sites in the national register maintained by Centro Nacional de Arte Rupestre (CNART) is 450. The only instance where it is legitimate to speculate that documented rock art may have been 'destroyed' is Vale da Casa. Examples of vandalized rock art panels are extremely rare, and generally are a result of popular ignorance, not of a deliberate intention to 'destroy'. For example, only two instances of 'enhancing' or addition of painted or engraved lines are recorded in that register: Mazouco and Abrigo do Gato, both in Trás-os-Montes. The practice of cutting and removing rock art motifs for commercial or museum purposes never existed in Portugal; only one example is known, the Pedra de Monte de Eiró (Penha Longa, Marco de Canaveses), removed in 1910 to the Municipal Museum of Oporto from a site destroyed in the early 20th century. There are a few examples of Tagus valley rock art motifs on display in the Castelo Branco Museum, but these correspond to loose panels that were removed by the archaeologists in the early 1970s, at the end of their study, as the area began to be inundated. A partly submerged loose panel recently identified at Vale da Casa was also removed and is currently on display in the headquarters of the Côa Valley Archaeological Park.
As of 1995, therefore, the overall state of preservation of Portugal's rock art was much better than in most other parts of the developed world. Colleagues interested in comparisons can only tabulate, against the data I provide here, the number of sites submerged by dams in rock art-rich countries with major hydroelectric power developments such as Canada, Norway, Russia, Sweden or the USA, or the number of rock art sites destroyed in Australia, Namibia, North America or South Africa by mining operations, by art robbers or by persons of European origin intent on causing deliberate damage to the cultural heritage of indigenous peoples.

\section{ON THE ENVIRONMENTAL IMPACT ASSESSMENT OF THE CÔA VALLEY}

1. In the late 1980s, the Electricidade de Portugal (EDP) decided to construct a massive holding dam ...[and] the archaeological heritage of the Côa valley was examined by a consultant whose specialization was Roman period sites.

In 1989, in the framework of environmental impact assessment work for the Côa dam, the company hired by EDP to conduct the relevant studies, contracted the Department of Archaeology of the University of Minho to conduct a survey of the area that was to be inundated. Francisco Sande Lemos was the archaeologist in charge. At the time, he was finishing a dissertation on the Roman period settlement of Trás-os-Montes, but he had begun his career studying the Palaeolithic and was, in fact, a founding member of the Grupo para o Estudo do Paleolítico Português (GEPP), the only entity dedicated to the study of the period that existed in Portugal in the early 1970s. He was also the discoverer of the Fratel rock art, in 1972, and the organizer of the survey and recording work subsequently carried out in the area, as well as the discoverer of Vale da Casa in 1983 (Sande Lemos, 1995). The implication of Bednarik's text is that the person in charge was the least qualified to conduct the survey, but the opposite is true. Bednarik should be aware of this, since Francisco Sande Lemos is one of the authors of the Serrão et al. (1972) paper included in Bednarik's bibliography.

2. He located some Roman building remains in the valley to be inundated ...

The Roman remains in question are the mutatio at Quinta da Ervamoira. These remains were discovered in 1984 by Guimarães, five years before Sande Lemos's survey, and have been under excavation without interruption since 1985 (Guimarães, 1995).

3 .... but made no mention of the prominent and numerous petroglyph sites there.

Given the short time he was given (two weeks), Sande Lemos adopted the strategy of leaving behind the final 
$6.5 \mathrm{~km}$ of the Côa valley that had been inundated since 1983 because of the Pocinho dam, located a few kilometres downstream from the confluence of the Côa and the Douro. At Vale de Moinhos, near the mouth of the Côa, he was nonetheless able to identify two panels with fine line engravings similar to those of Vale da Casa. Only upriver from the tail of the Pocinho reservoir was the valley surveyed more systematically at this time. This resulted in the discovery of the Faia ensemble of rock paintings, one of the most significant components of the Côa valley rock art in the area proposed for flooding.

4. These major corpora of rock art were well known to local residents...

Older local residents knew well the engravings of trains, boats, birds, the Sun and the moon, motifs of Portuguese history and clocks, made in the valley by millers in the 1940s and 1950s (García and Luís, 2002). After the discovery of the Palaeolithic art was publicized, older local residents talked of being aware that rocks at the bottom of the Douro and Côa were 'tattooed', but there is not a single instance where local residents identified such 'tattooed rocks' as prehistoric rock art before 1995. Only one major rock art location with large pecked images was discovered by a local resident, not by the archaeologists involved: the sites of Penascosa/Quinta da Barca, identified in early January 1995 by Mr Adriano Ferreira. His account of the discovery (of which Bednarik must be aware, since he has used and cited it in the past - e.g. Bednarik, 1996) was published in the weekly magazine Visão (26 October 1995). After having seen images of Canada do Inferno on TV, Mr Adriano Ferreira thought that an area where he had used to fish for 30 years and which featured similar kinds of rock surfaces may also have decorated panels. He went there with the idea of making a detailed inspection of those rock surfaces to which he previously had paid no specific attention, and that is when he realized that they bore engravings of animals similar to those publicized by the media as Palaeolithic rock art.

That the prehistoric art of the valley had gone largely unnoticed by the local residents is due to the fact that the grooves defining the motifs are patinated to the same extent as the rock surface, and that, prior to discovery, they were variably covered by lichen growth; moreover, the rock surfaces themselves were hidden behind shrubs that had to be removed for proper access, recording and visitation. In these circumstances, it takes an experienced trained eye, or extremely favourable lighting conditions, to recognize the presence of the art. Even when such ancient art may have been recognized (and there is indirect evidence as well as oral testimony that one of the millers who engraved in the valley in 1940s and 1950s, José Alcino Tomé, was aware of the large animal engravings at Canada do Inferno and may even have been inspired by them - García and Luís, 2002), the lack of formal education (beyond basic arithmetic, reading and writing) of these persons, the remoteness of the area, the under-development of archaeology as a profession in Portugal until the mid 1970s, the fact that emigration entailed abandonment of human use of the valley bottom after the early 1950s (for example, the persons whose names are recorded alongside those 1940s and 1950s engravings, José Alcino Tomé and António Seixas, left the country for Mozambique and France, respectively, soon after), all of this explains why news of this art never reached the world of archaeology until the 1990s.

5. ... and had been studied by a local medical doctor some decades earlier.

Abreu et al. (2003) claim that the local doctor, José Silvério de Andrade, discovered the Côa Valley rock art in 1939. They base this claim on an incorrect interpretation of a section of Andrade (1940) where the monuments of the Foz Côa municipality are discussed. Six lines in the description of the antiquities of Castelo Melhor, a village of that municipality, refer to engravings (of fish, snakes, a horse head with reins, a bird taking off for flight) made on loose blocks. Given the context, the technique mentioned and the nature of the motifs, Andrade is probably describing the kind of recent engravings pecked onto the individual blocks making up field- or yard-delimiting walls that, to this day, can be observed lining the street of Rua dos Namorados, inside the village of Castelo Melhor. It is in any case clear that Andrade's reference is unrelated to the prehistoric rock art in the Côa valley proper.

6. the study recommended ... that a team of archaeologists be employed during the dam's construction.

Sande Lemos's report classified the Faia rock art as of exceptional importance, suggested that many other ensembles such as those at Vale da Casa and Vale de Moinhos might exist under the waters of the Pocinho reservoir and recommended that further survey be conducted before a final assessment of the dam's impact on the valley's heritage. The independent commission that evaluated the environmental impact assessment study supported this recommendation and, in fact, in January 1992 conditionally approved the study pending the results of such additional archaeological investigations (O Independente, 17 February 1995).

It was Instituto Português do Património Arquitectónico e Arqueológico's (IPPAR) decision to accept Sande Lemos's preliminary and incomplete survey as the basis for the salvage work to be carried out at the same time the dam was being built, and to consider such salvage work as sufficient mitigation. An agreement to that effect was signed between IPPAR and EDP in 1993. This was the seminal and fundamental error of management made in the Côa.

Before 1993, a single agency, the Instituto Português do Património Cultural (IPPC), managed all cultural heritage in Portugal; it was split at that time into IPPAR (for the management of architectural and archaeological heritage), 
and Instituto Português de Museus (IPM) for the management of museums. Within the framework of this reorganization, the nationally co-ordinated regional services of archaeology that existed within IPPC were replaced at all levels of IPPAR by integrated structures in which archaeologists were a minority and in which archaeology had lost its previous significant level of administrative autonomy. This was a major error, and explains to a large extent why IPPAR dealt so inadequately with the Côa situation.

\section{ON THE HISTORY OF THE CAMPAIGN TO SAVE THE CÔA VALLEY ROCK ART}

1. In 1992, an archaeologist appointed by IPPAR recognized the presence of a large corpus of rock art in the area to be inundated ... During November 1994, the waters of the adjacent Pocinho dam ... were lowered to allow the erection of two coffer dams. During this period the archaeologist was able to discover significant numbers of further motifs that had been flooded in the previous decade.

The archaeologist in question is Nelson Rebanda. The lowering of the Pocinho dam for the erection of the Côa coffer dams was carried out in the summer of 1993, not in November 1994. According to Rebanda's own account (Rebanda, 1995), until that lowering, only one more rock art panel had been added to the list in Sande Lemos's report (Rock no. 1 of Canada do Inferno - evidence on file at CNART indicates that Rebanda had identified this panel in 1991), and six others were identified below the Pocinho level, at different times between the summer of 1993 and the summer of 1994. Until November 1994, when the existence of this art complex was first publicized by IPPAR, finds of prehistoric rock art in the Côa valley were restricted to Vale de Moinhos, Canada do Inferno and Faia. All other sites were identified subsequently.

2. When the Pocinho dam was about to be refilled, he requested that the Portuguese Representative of IFRAO should come and see the rock art two days before its final inundation in late November.

In late November 1994, Nelson Rebanda contacted not only Mila Simões de Abreu from IFRAO, but also António Martinho Baptista and Mário Varela Gomes. The latter could not get to the Côa at that time but Baptista did, and visited the sites a few hours after Abreu had been there.

3. IFRAO declared that the destruction of the rock art was unacceptable.

What exactly happened during the conversation between Rebanda and Abreu is known only to the two of them. Anyone willing to accept Abreu's version, however, must be aware that such a version, as published in a local newspaper of the nearby town of Torre de Moncorvo, was the subject of eventually successful defamation proceedings brought by Rebanda against Abreu (Público, 18 January 2000). For Abreu's version of this incident, see http://rupestre.net/ tracce/12/appeal.html.

4. ... within days [IFRAO] commenced a campaign to prevent the flooding of the lower Côa valley ... a series of actions by IFRAO and allied interests led to increasing international condemnation during early 1995.

As soon as the existence of the Côa art was first publicized in the media (cf. Público, 21 November 1994), many different persons and institutions in Portugal, archaeologists and non-archaeologists, demanded a thorough investigation of the situation and, in particular, given that IPPAR had proven itself incapable of adequately dealing with it, that an independent commission of experts be appointed to evaluate the real age and potential significance of the finds. The first person to make a public call for the definitive abandonment of the Côa dam and for the management of the valley's rock art as an Archaeological Park was Portuguese archaeologist Cláudio Torres (Expresso, 24 December 1994). Many colleagues from all over the world wrote letters to the Portuguese authorities alerting them to the importance of the rock art, and members of IFRAO contributed to these protests; but it is totally unjustified for Bednarik to claim for himself and for IFRAO any leading role in the unfolding of the events.

5. Within Portugal, public opinion was mobilized through a civic action group, the Movimento para a Salvaguarda da Arte Rupestre do Vale do Côa, and the world's first public demonstrations in favour of rock art protection were organized in Foz Côa and Lisbon. One million signatures were collected in a petition to save the valley, a public protest fast was held in Lisbon ...

The Movimento Bednarik refers to was a creation of his associate, Abreu, and its role in the protests was insignificant. A demonstration in favour of the preservation of the Côa rock art was indeed staged in Vila Nova de Foz Côa, on 3 February 1995, but as an initiative of the local high school students and their teachers. The same students and teachers organized a petition to save the art which, according to the high school principal's own account (Ribeiro, 1995: 40), collected 200,000 signatures, not one million. On 24 April 1995, Abreu and friends staged a public fast in front of the Jerónimos Monastery, a major tourist attraction in Lisbon. It lasted until 12 May and was then abandoned, not because of police brutality, but because the fasters complied with orders to leave, given within the framework of security measures for a wedding ceremony to be held in the Monastery's church that involved the presence of high-up state officers. 
6. By May 1995, the government was forced to halt all construction work at the dam site, having already spent in excess of US\$100 million.

In May 1995, orders to halt construction were in fact given, and respected as far as the actual concrete wall of the dam was concerned, but EDP nonetheless continued parallel work in the valley. At that time, EDP, not the Portuguese government, had already spent in the order of US $\$ 5-10$ million in construction work. A sum in excess of US $\$ 100$ million is the compensation that the Portuguese state paid to EDP as a result of the decision made by the government, elected in October 1995, to abandon the dam project altogether.

\section{ON THE AGE OF THE CÔA VALLEY ROCK ART}

1. In the case of the Côa rock art it is generally acknowledged that a great part of it dates from the last two or three centuries.

This is indeed the point of view of Bednarik and his associate Alan Watchman. To the best of my knowledge, it is nobody else's. The World Heritage Committee listed the Côa valley rock art because 'The Upper Palaeolithic rock-art of the Côa valley is an outstanding example of the sudden flowering of creative genius at the dawn of human cultural development' (http://whc.unesco.org/archive/repcom98.htm\#866). Public Archaeology readers can themselves decide on what qualifies better as a measure of 'general acknowledgement': Bednarik's views as published in the journals and newsletters of which he is the corporate owner, or UNESCO's listing based on the scientific evidence published in peer-reviewed journals (cf.Zilhão, 1995; 1998; Zilhão et al., 1997) and on the expertise of the ICOMOS panel of rock art specialists.

2. A relevant lesson from the Côa controversy was that 'the political nature of the archaeologists' strategy influenced their scientific discourse'...: to preserve their claim that the rock art is of Palaeolithic age, they tied its preservation to this age claim and, in fact, demanded that it must be preserved because it is of Palaeolithic age.

Portuguese archaeologists, myself included, who argued in favour of a Palaeolithic age for the stylistically Palaeolithic Côa valley petroglyphs did so because they were sincerely convinced, on the basis of the available scientific evidence, that such was the case (and they were eventually proven right). In contrast, it is Bednarik's associate, Abreu, who admitted to the media that, in 1995, she maintained that the Côa engravings were of Palaeolithic age only because it was a politically useful argument. In defence of this, she provided the explanation that, in the battle against the dam, all means were justified to achieve the intended purpose $(O$ Independente, 30 May 1997).
That the age of the Côa valley rock art plays a major role in the definition of its significance is made clear by the fact that only its prehistoric component is listed by UNESCO as World Heritage. Nomination by the Portuguese government, dated 24 June 1997, was for the listing of the "National Monument of the Côa River Valley Archaeological Sites (Portugal)', created by Decree-Law 32/97, published in the official journal, Diário da República, on 2 July 1997; this National Monument includes all archaeological sites in the valley, both prehistoric and historic, as well as all of the rock art. UNESCO's World Heritage Committee, however, decided that only Palaeolithic rock art was worthy of the status. That is why the site is described in the World Heritage List as 'Prehistoric Rock Art Sites in the Côa Valley', and that is why its Brief Description in the List is as follows: 'this exceptional concentration of rock carvings from the Upper Palaeolithic (22,000-10,000 B.C.) is the most outstanding example of early human artistic activity in this form anywhere in the world' (http://whc.unesco.org/sites/866.htm).

3. This was a fundamental error of strategy in several respects ... such an equation is unacceptable to rock art researchers and site managers worldwide, as it would prejudice demands for preserving Holocene rock art elsewhere.

The truth is that Bednarik himself is the only person who tied the preservation of the Côa petroglyphs to the argument that a Holocene age would make them unimportant. In a letter dated 24 March 1995 letter, he offered EDP his services as a 'dating expert' on the basis of the following argument: 'These considerations show an urgent need for scientifically credible research to establish the true age of the rock art, and to resolve the question of its preservation. These are the most important issues at hand: if the art were to be shown to be post-Palaeolithic, its importance would diminish dramatically and the controversy concerning its preservation would be largely resolved'. I regret that, for reasons of copyright, the Editor has not felt able to reproduce this letter as an Appendix.

\section{ON POST-1995 RESEARCH AND MANAGEMENT OF THE CÔA VALLEY ROCK ART}

1. ... the new government ... established two new state agencies, the Instituto Português de Arqueologia (IPA) and the Centro Nacional de Arte Rupestre (CNART), to replace IPPAR.

IPA inherited most of the responsibilities for the management of archaeology previously held by IPPAR, but did not replace it. IPPAR (renamed as Instituto Português do Património Arquitectónico) continued to exist alongside, with responsibilities restricted to the management of archi- 
tectural heritage and classified sites. CNART was created as a research department within IPA. At the same time, Parque Arqueológico do Vale do Côa (PAVC) was also created within IPA as a department for the management of the Côa valley sites.

2. In the Côa valley, now protected by World Heritage listing, recording and cleaning of rocks by inappropriate methods continued (Jaffe, 1996).

The World Heritage listing of the Côa valley was in December 1998; in 1996, it was not yet protected.

3. Various chemicals, including bleach, were applied directly to the petroglyphs, and they were scrubbed with wooden tools, according to the written admission by the Director of IPA (Zilhão, 1996) and scrubbing of the Côa petroglyphs was politically motivated.

Throughout 1995 and 1996, for research-recording and visibility-enhancement purposes, some decorated rock surfaces were cleaned of lichen using only river water, not chemicals or bleach, and soft wooden tools. These were used to remove the lichen, not to scrub the petroglyphs. The source cited by Bednarik is a letter to IFRAO 1996 President, Shirley Ann Pager, where these and other issues were clarified. I provide a copy as an Appendix so that readers can make up their own minds as to the nature of my 'admissions' and 'motivations'.

Where the lichen issue is concerned, an International Commission on Conservation and Management co-ordinated by Nicholas Stanley-Price (currently the director-general of ICCROM) that, at IPA's request, evaluated the Park in 1997, stated: 'The commission inspected the rock art panels from which lichen has been removed for the purposes of recording and for improving the visibility of the rock engravings. It found no evidence, on the basis of close visual inspection, of damage caused to the rock art surfaces by the removal of lichen (Stanley-Price et al., 1997). To this day, no chemicals have been used in Côa, even though the use of biocides was recommended by the expert opinion (Romão, 1999) ordered by the Park following the recommendations of that Commission.

4. In an attempt to locate evidence of Pleistocene occupation numerous sites were churned up, and researchers not associated with these works were excluded from the sites by security guards (Swartz 1997a; 1997b).

Swartz (1997a) refers to observations made by him in June 1995, when EDP/IPPAR were in charge of the sites, and which are not relevant to the issues raised by Bednarik. Swartz (1997b) refers to his investigation, at the request of IFRAO, of charges against me made by Ludwig Jaffe in August 1996. This is what Swartz (1997b) actually says: 'Jaffe levels nine specific charges at the Ministry archaeologists. None of the charges are documented by Jaffe, only asserted, and none are specifically denied by Zilhão! This creates a ludicrous situation for an outside investigation. For a comprehensive investigation to be done it is necessary to solicit or subpoena direct face to face testimony in Portugal from the individuals involved. This is beyond my personal means and that of IFRAO'. In fact, Swartz never contacted me, or visited the Côa again, to verify the validity of the accusations, all based on, in his own words, 'hearsay' from unidentified sources.

In fact, the 'churned up' sites were archaeological trenches opened at the foot of three Penascosa panels in August 1995, for geological purposes, into recently accumulated, sterile, sandy alluvial deposits. The 'exclusion by security guards' refers to an incident with Bednarik's Portuguese associate, Abreu, that took place on 29 July 1996. Turning up at Penascosa at a time when a school group was already there, she and her group were courteously told to wait their turn. Faced with Abreu's improper reaction, the PAVC archaeologist accompanying the students had no choice but to ask security guards to escort Abreu's group out of the area until the school visit ended. Ever since I was given responsibility for the management of the Côa sites, beginning 1 January 1996 , any and all researchers who requested it have been able to visit them with no restrictions.

A member of the American Rock Art Research Association (ARARA), Jane Kolber, was in Abreu's group. In a personal letter to Bill Hyder, President of ARARA, dated 22 January 1997, I provided clarification of all these issues to his full satisfaction. For those with an appetite for the details, I hereby provide authorization for the public dissemination of this six-page-long letter, should anyone be interested in requesting a copy from Hyder.

5. Public sites still lack any form of interpretation for visitors ...

A detailed description of the way public sites are interpreted for visitors can be found in Zilhão (1998).

Since Bednarik gives Australia as an example to be followed in the management of archaeology and rock art, it must be relevant that the minutes of the December 1998 Kyoto meeting of the World Heritage Committee record that, upon the Committee's vote in favour of the inclusion of the Côa valley rock art in the World Heritage List, 'the Delegates of Australia and Morocco warmly welcomed this nomination for contributing to the diversity and credibility of the World Heritage List and commended the State Party on its management of the site' (http://whc.unesco.org/archive/ repcom98.htm\#866). The delegate from Australia was Sharon Sullivan, from the Australian Heritage Commission.

By the same token, the opinion of Australian participants in the May 1999 symposium organized by IPA in Vila Nova de Foz Côa with the managers of rock art sites in the World Heritage List (Stanley-Price, 2000) must also be relevant here. The Australian delegation included representatives of the aboriginal owners of Kakadu and Uluru National Parks. After visiting the Côa Park and its rock art sites, the two 
aboriginal elders representing the owners of Uluru commented that 'the Park is very well organized, there are very strict rules and visitors are guided by people that understand what they show. This is a good way to take care of a Park.' (Público, 16 May 1999).

An independent study (Lima and Reis, 1998, 2001) of the composition of the Park's public carried out in 1998 by opinion poll company Euroexpansão for a team of the Instituto Superior de Ciências do Trabalho e da Empresa (ISCTE, University of Lisbon) allowed the establishment of a sociological profile of the adult public visiting the Park in the summer. Asked about the degree of satisfaction, the polled sample replied that it was 'satisfied' (98\%) or even 'extremely satisfied' (64\%) with the visit, and that the performance of the guides significantly contributed to such satisfaction; these values are all the more significant because a majority of the sample $(59 \%)$ held a university degree $(45 \%)$ or had been to university but not completed their studies $(14 \%)$.

6. ... no attempt has been made to reduce dust generated by vehicular traffic.

No vehicular traffic is allowed in the Côa valley rock art areas. Visitors are transported to the public sites from Visitor Centres set up in nearby villages and only in PAVC-owned vehicles or those of private tour companies with a PAVC permit to operate in the area. Parking areas for these vehicles were prepared within walking distance (5-20 minutes) of the public sites. No vehicles approach the rock art closer than this.

7. ... CNART tour guides offer interpretations that are simplistic and lack scientific credibility.

Tour guides are not CNART's but PAVC's. The quality of their interpretation has been evaluated in the report of the above-mentioned International Commission on Conservation and Management: 'The members of the Commission were very impressed with the general management and would like to congratulate the management staff of the park. The research, the planning, the documentation, the management, the training of guides and the infrastructure work (such as the visitor reception centres) are all excellent. The thoughtful planning and the quality of the visitor experience show intelligence, enthusiasm and exceptional teamwork. Many of the good examples of innovative management would have international application' (Stanley-Price et al., 1997).

\section{ON THE CONSTRUCTION OF A DAM IN THE SABOR RIVER}

1. Already in mid 1995, at the height of the Côa confrontation, the previous government had sought an alternative dam site in the event that it would lose its bid to complete the Côa dam. It found it in another tributary, the Sabor, where it soon began construction of the Laranjeira dam.

The intention to build a dam in the Sabor river to replace the abandoned Côa project was announced by the government elected in October 1995, and the necessary environmental impact studies and preliminary work (geotechnical testing, opening of roads) was initiated but, to this day, construction of the dam has not begun and no definitive decision to actually build it has been made. The chosen location's name is Quinta das Laranjeiras, not Laranjeira.

2. Visitors were excluded from the valley and, although it is known that rock art exists there, no reports of it were made public (Arcà et al., 2001).

Visitors have never been excluded from the Sabor valley, and could not possibly be in the first place, because this is a vast unfenced area where, under Portuguese law, the circulation of persons is free. Results of the Sabor environmental impact assessment study are public documents that can be publicly consulted with no restrictions. In fact, Arcà et al. (2001), of which Bednarik is one of the authors, quote such a study.

Zilhão (2001a) contains formal reference in an archaeological publication to the engraved aurochs from Ribeira da Sardinha, the single Palaeolithic petroglyph in the area to be inundated if the Sabor dam is eventually built. A very small number of petroglyph panels from later periods may also be affected.

\section{ON THE ALQUEVA DAM IN THE GUADIANA RIVER}

1. Of particular concern is that both the impact studies and the archaeological salvage work were conducted under the authority of Empresa de Desenvolvimento e Infraestruturas de Alqueva, which is the very same agency that built the dam. The concept of a conflict of interest does not seem to have been appreciated ...

Extensive accounts of the Guadiana controversy and the background to construction of the Alqueva dam are provided in Zilhão (2001b) and Zilhão and Baptista (2001), to which readers of Public Archaeology are referred for further details. Suffice it to say here that, under Portuguese and European Union laws, the realization of environmental assessment impact studies (which include impacts on cultural and archaeological heritage), and the application of the mitigation plans derived from them, is the responsibility of the developer, in this case the company building the dam, Empresa de Desenvolvimento e Infraestruturas de Alqueva (EDIA). The latter therefore bore all responsibility for the archaeological survey and salvage excavation work carried out in connection with construction of the Alqueva dam. 
Regulatory authorities such as IPA approve the plans, check on their execution, recommend any necessary changes during implementation and, at the end, advise governments on whether the final implementation was indeed sufficient mitigation of a project's environmental impact. Throughout the development of the project, independent Accompanying Commissions with representatives of government agencies, the public and NGOs provide further checks on the implementation of mitigation plans.

2. The entire purpose of CNART is to study and protect the rock art of Portugal, yet it claims it took no interest whatsoever in either the country's largest site complex or its largest construction project.

CNART never made such a claim and, in fact, undertook the task of inventorying and recording the Guadiana rock art (see below).

3. It was precisely this painful experience in 1995 [the Côa fiasco] that was directly responsible for the establishment of IPA and CNART, yet in all subsequent years, it is claimed, it never occurred to these organizations to examine the location of the largest reservoir ever built in Europe to see if rock art was affected.

IPA was created in 1997; salvage work in the Guadiana began in 1998 and throughout 1998 and 1999 IPA repeatedly alerted EDIA to the fact that a dedicated survey in relation to rock art had not been carried out before the setting of the terms of reference of the mitigation plan and was badly needed (cf. the minutes of the meetings of the Cultural Heritage Workgroup in the Alqueva Accompanying Commission, GTPC (Grupo deTrabalho do Património Cultural), 1999a; 1999b; 2000; 2001). It must be stressed that IPA was the only organization that acted on this issue at this time. Before April 2001, neither IFRAO as such, nor IFRAO's Portuguese representative (Bednarik's associate, Abreu) voiced any concern about the possibility that rock art undetected during the pre-1997 survey work could exist in the Guadiana.

EDIA eventually complied with IPA's recommendations and, after failed attempts at hiring a consultant for the job, suggested that CNART itself organize a survey mission in the valley. That mission was initially planned for October 2000, but EDIA then decided to delay it until the spring of 2001 because of logistical problems.

4. Although approximately 100 archaeologists were working on this project by $2001 \ldots$ no finds of rock art were reported. In April 2001, however, Spanish researchers described finding a large number of rock art sites in the small area of Spanish territory that was to be inundated by the dam....

In November 2000, the relevant Spanish authority (the Junta de Extremadura) contacted EDIA informing it of the existence of the site of Molino de Manzanares, near Cheles, whose existence had just been divulged through preliminary archaeological publication (Cerrato and Novillo, 2000). Recording work immediately contracted by EDIA to the Badajoz Museum began in January 2001, in spite of adverse conditions.

5. Yet there were still no reports from the much greater Portuguese sector of the area. An environmentalist ... $\mathrm{NGO}$ then received an anonymous tip-off that a large corpus of rock art sites also existed on the Portuguese side.

Preliminary results of the Cheles work were publicly presented at a rock art conference held in Tomar, Portugal, in early April. That presentation prompted Manuel Calado, an archaeologist working for EDIA in the salvage of nearby Iron Age settlements, to start his own search. His first finds were made across the river from Molino de Manzanares, in mid April; he returned to the area on 25 April and found several other panels. The following day, Manuel Calado emailed a personal message to me, and then an official one, communicating the finds. The news was immediately made public through an IPA press release and posted the following day, 27 April 2001, at 12:00h, with photos, on IPA's website.

6. IPA finally admitted the existence of several hundred sites in the Portuguese area to be inundated.

IPA always suspected that undiscovered rock art existed in the Guadiana and since 1998 had been demanding from EDIA that a dedicated survey be carried out.

The total number of sites to be inundated on the Portuguese side is one, Moinho da Moinhola, plus a number of scattered occurrences of isolated panels; in total, the number of decorated rocks on the Portuguese side of the river is 240 (118 of them at Moinho da Moinhola), and $95 \%$ of the decorations are circles and spirals. The total number of decorated rocks in all of the inundated area, including Spain, is c. 1000 , for the most part concentrated at the single Spanish site of Molino de Manzanares.

7. [IFRAO] ... launched a petition to save the Guadiana rock art, which attracted the support of thousands of specialists and heritage administrators, and of the International Union for Prehistoric and Protohistoric Sciences.

At the time IPA announced the discoveries on the Portuguese side, publication of the site of Cheles was already six months old, and its identification and recording had been in progress for four months, under the auspices of EDIA and the relevant Portuguese and Spanish authorities. Yet it was not until the far less important Portuguese discoveries that IFRAO and its national representative initiated a media campaign against EDIA, IPA, myself and the Portuguese state. Moreover, as it soon turned out, written reports of the existence of the Cheles engravings, including 
photos, had been presented to the Junta de Extremadura by local residents in 1993, and remained on file there ever since (Collado, 2001). Neither the Portuguese state nor EDIA nor IPA can be held responsible for the fact that it took the Spanish authorities seven years to communicate the existence of these engravings. Interestingly enough, however, neither Abreu nor Bednarik nor any of their IFRAO associates ever uttered a single word of criticism against the Spanish state, Spanish archaeology or Spanish archaeologists in relation to the time it took for the Junta de Extremadura to act on the rock art located on the Spanish side of the Guadiana. These facts suggest that IFRAO found it acceptable that the Alqueva dam should flood Spanish rock art and that only the flooding of Portuguese rock art was unacceptable to them, but they never clarified this point.

The truth of the matter is that, in fact, IFRAO never demanded that the Alqueva dam be stopped. In the Portuguese version of its position (Abreu, 2001a), IFRAO accepted that the Alqueva dam was irreversible ('sendo a construção da barragem irreversível, a destruição de tão importantes achados é praticamente inevitável' - 'since the construction of the dam is irreversible, the destruction of such important finds is practically unavoidable'), although, in the English version (Abreu, 2001b), this was translated as 'the dam is nearly finished and it will be difficult to avoid the destruction of this important rock-art area'. In both versions, the specific demands made of the Portuguese government were: 'to do everything possible to investigate the engravings with the most appropriate and up-to-date methodology and with adequate time to do so'; and that, in the carrying out of the recording work, EDIA, IPA and CNART be replaced by 'suitable specialists' indicated by IFRAO.

An online petition started by someone identified as Bill Laben (http://www.petitiononline.com/Alqueva/ petition.html) did indeed 'urge that you [the Portuguese government and European Union] suspend the Alqueva Dam project immediately'. On 19 September 2001, several months after it was launched, only 1409 people had signed it. On 25 May 2003, the 'total number of signatures' indicated for this petition in that website was 2560; looking up their names, it is clear that only very few qualify as specialists or heritage administrators.

This petition was not supported by any of the different bodies representative of the archaeological profession in Portugal. It was not supported by the International Union of Prehistoric and Protohistoric Sciences (IUPPS) either. In its September 2001 Liège meeting, the IUPPS passed a motion (IUPPS, 2001; http://rupestre.net/tracce/13/ uispp.html) with the simple demand that everything is done to make sure that the engravings are exhaustively inventoried and that their systematic study is completed before the dam goes into operation ('tout doit être fait pour que les gravures soient exhaustivement inventoriées et que leur étude systématique ait lieu avant que le barrage ne puisse finalement être mis en fonction'). It also decided to send a mission to inspect the Alqueva work.
Thus, the whole Alqueva campaign against IPA, CNART and myself ended up in a double absurdity. Firstly, we, as well as the Portuguese state, were accused of negligence in relation to the late discovery of the art, whereas no criticism was made of the Spanish authorities who had possessed the information for seven years and done nothing about it. Secondly, not questioning that the reservoir be filled, and not demanding that construction of the dam be abandoned, IUPPS's and IFRAO's representative in Portugal asked that more time be given to the archaeologists in the field to complete their studies - in spite of the fact that the archaeologists in the field stated that they did not need more time! Since Bednarik endorsed the IUPPS inspection, and this mission was severely criticized by me (see below), there can be no doubt that its findings must be relevant in this context: 'Il semble, aux dires des archéologues responsables des chantiers d'art rupestre, que l'on dispose de sufisemment [sic] de temps pour terminer l'inventaire.... Pour les autres sites archéologiques également, le temps imparti à la recherche sur le terrain semble suffisant, même si les archéologues ont parfois été confrontés à des problèmes d'évaluation des prospections préparatoires' (http://www.alquevaarqueologia.net/main.php?pag=docgrave $\left.\& \mathrm{tx}=\mathrm{doc} \_016\right)$.

That campaign is also based on equating inundation with destruction, which, in the Guadiana case, is incorrect. Inundation prevents access to the art throughout the Alqueva dam's lifetime but does not necessarily destroy the rock art; given the nature of the bedrock and the experience of the Tagus rock art, which after 30 years of submersion remains in pristine condition (see above), there is no indication that the Guadiana rock art will not survive intact through the period of submersion. In fact, the fluvial patination of many of the petroglyphs indicates that they have been subject to river erosion ever since they were made. Situated right on the banks, 2-3m above the river on average, they must have been covered by water and sand every time there was a major flood. In the Guadiana, such floods may entail a rise in the water level of up to $20 \mathrm{~m}$, and have occurred every few years for the four or five millennia since the art was produced.

The situation in Côa was very different from that in the Guadiana. Not only was the art far more important (see below), it was also engraved on the vertical surfaces of highly fissured schist outcrops located on very steep, unstable slopes (Delgado Rodrigues, 1999). In the Guadiana, the decorated surfaces are horizontal and located for the most part in gently sloping terrain along the river margin or in the river bed itself. In the Côa, submersion would have entailed destruction, or definitive burial under tens of metres of eroded sediments. There is no indication that such will be the outcome in the Guadiana.

8. The Director of IPA suggested publicly that the reason his teams may not have seen the rock art was because it was perhaps covered by river sand. So, he is suggesting that during the 16 years that the valley was studied, 600800 petroglyph sites were covered by sediment, but in early 2001 they were all miraculously uncovered. 
No IPA teams were involved in the survey of the Guadiana rock art until April 2001, hence no IPA teams could possibly have seen it before that time. Moreover, IPA was not and could not possibly have been involved in the previous 16 years of study because it was only created in 1997.

What I actually 'publicly' said is the following: 'A significant portion of the work carried out over the last few months consists precisely in taking advantage of the dry season to remove the river-bottom sands from under which outcropping boulders are visible, in order to find out whether they are decorated, and record them if that's the case' (Zilhão, 2001b).

9. He also claimed that the rock art was not sufficiently important to warrant its preservation ...

I argued that the Guadiana rock art was of national importance, not world importance, as was the case with the Côa art. I also argued that, given that its preservation in the long run was not at stake, only loss of access and visibility, exhaustive recording and study were sufficient mitigation (Zilhão, 2001b). This view was unanimously shared in Portugal, and even Bednarik's associate, Abreu, refrained from questioning such a view in her statements to the Portuguese media (cf. Expresso, 25 May 2001).

10. ... but at no time did he admit that the rock art's existence had been concealed.

I did not admit that the existence of the rock art had been concealed simply because it had not been concealed.

11. In September 2001 the Union of Prehistoric and Protohistoric Sciences voted to appoint a committee to investigate the Guadiana issues.... This led to a scathing response by the Director of IPA ... and to other unbecoming attacks by him on various individuals and international organisations, which resulted in defamation proceedings.

The 'scathing response' cited by Bednarik is a truncated version, edited by him, of my true response (Zilhão, 2001b), which Bednarik published in Rock Art Research without my knowledge, let alone permission. I know of no defamation proceedings initiated against me, in Portugal or anywhere else in this world, as a result of that response. The only person in Portugal who has been successfully sued in court for defamation of an archaeologist is Bednarik's associate, M.S. Abreu (see above).

12. During June 2002, the major Guadiana rock art concentrations at Cheles were inundated. Most of the valley's rock art has remained unrecorded and, where records do exist, they do not meet any reasonable international recording standards ... Moreover, the teams involved in the recording work were inadequately experienced in modern methods and lacked even rudimentary relevant equipment.
More than $90 \%$ of the valley's rock art has been recorded through tracing, photography and, for some selected panels, three-dimensional laser-scanning. Where the quality of the recording work is concerned, the findings of the IUPPS mission endorsed by Bednarik (cf. Appendix 3) were the following: 'Nous tenons à insister sur le fait que les travaux effectués tant par les collègues espagnols que portugais répondent dans une très large mesure aux normes scientifiques modernes'.

\section{ON POST-1995 PUBLIC ARCHAEOLOGY IN PORTUGAL}

1. [T] he socialist government from 1995 to 2002 pursued precisely the same policies as the conservatives.

The government elected in 1995 cancelled the Côa dam project, which its predecessor wanted to build, successfully nominated the Côa Valley rock art for the World Heritage List, set up an Archaeological Park to manage it and created the autonomous agency for the management of archaeological heritage (IPA), which its predecessor had refused to do in spite of a long history of demands from the profession for the creation of such an agency.

2. But, after its predecessors' experiences, its public archaeology developed a secretive and exclusive format, rejecting any external scrutiny and giving precedence to what it defined as the 'national interest'. New national projects were conducted under explicit conditions of exclusion...

In this period, the two 'national projects' Bednarik conceivably refers to were the Côa Valley Archaeological Park and the Alqueva Dam Archaeological Salvage Work. The data provided below should be sufficient evidence of the extent to which these projects were always open, effectively submitted to external scrutiny and evaluated in very favourable terms in the framework of such scrutiny.

Where the Côa Park is concerned, from the beginning, all work was accompanied by an external consultant, Nicholas Stanley-Price (the current head of ICCROM). The scientific research conducive to the establishment of the chronology of the Côa valley's art and its archaeological context was evaluated in January 1997 by an international commission of experts composed of Paul Bahn (UK), Michel Lorblanchet and Dominique Sacchi (France), Sergio Ripoll, Rodrigo Balbín and Valentin Villaverde (Spain). This commission validated the scientific report prepared under my responsibility. It was on the basis of this report and international validation that the Portuguese government formally abandoned the Côa dam in 1997. The report is published in Portuguese as a 453-page monograph (Zilhão, 1997), and an English summary is published in the peer-reviewed Journal of European Archaeology (Zilhão et al., 1997). Issues of conservation and management were evaluated in 
July 1997 by the international commission mentioned above (Stanley-Price et al., 1997). Listing of the property as World Heritage was based on an inspection and report by Ulf Bertilsson, the current President of the ICOMOS Committee on Rock Art, which took place in February 1998.

Where the Alqueva Dam is concerned, the Annual Meeting of the European Association of Archaeologists, held in Lisbon in 2000, offered participants the opportunity of a pre-conference excursion to the Alqueva, so that the work carried out there could be presented and discussed. Eventually, the excursion did not take place because there were not enough participants, but two American colleagues, Tom Wheaton and Chuck Niquette, visited the area. On 11 May 2001, in the wake of IFRAO's accusations against IPA, EDIA and myself, Tom Wheaton, then acting chair of the USA's ICOMOS specialized committee on Archaeological Heritage Management, posted a web announcement (http:/ /lists.nonprofit.net/archives/acra-1/2001-May/009111.html) containing the following statements:

Recently, several archaeological mailing lists have received messages loudly proclaiming conflicts of interest, incompetence and even wilful ignorance on the part of the Portuguese archaeologists involved in the Guadiana/ Alqueva Dam project. As it happens, Chuck Niquette and I are probably among the very small number of American archaeologists who have actually visited the project. We spent two days last fall touring the project area, meeting the archaeologists working on sites ranging in date from Palaeolithic through Iron Age to Roman and nineteenth century. The archaeologists working on these excavations work for private firms and universities, so that Portugal is now one of the top three or four countries in Europe with a vibrant private sector. Chuck and I saw the labs, the reports and the database and GIS systems as well. While I do not pretend to be an expert on the project, as two days is not very long to learn about the largest CRM project in Europe on the largest reservoir ever built in Europe, I will say that I was very impressed with the scope and size of the project; the willingness of the construction company, EDIA, to do what was necessary to survey and mitigate site impacts, and to be flexible on the project's scope as new things are found; and the overall management of the project. It is without doubt a better run project than most of the large reservoir projects I have seen in the past 20-30 years in the US. Just the quality of the public outreach publications (for school children and the general public) while the project is still ongoing puts most projects in the US to shame.

3. .... and, in order to work within this system, archaeologists had to meet specific requirements of confidentiality.
In the Alqueva project, contracts signed with EDIA by individual archaeologists or CRM companies involved in the salvage work contained the commercial confidentiality clauses that are to be expected between contractor and contracted consultant; specifically, the consultant's obligation to request the company's consent before publishing results from field work. EDIA approved all such requests. In any case, in Portugal, interim field work reports have always been mandatory and, by law, communicated directly to the regulatory authority, IPA; they are in the public domain and subject to no specific requirements of confidentiality.

\section{ON POST-2002 PUBLIC ARCHAEOLOGY IN PORTUGAL}

1. The newly [in March 2002] elected government wasted no time in acting on the state of public archaeology in Portugal, the reputation of which even the Director of IPA admitted was in tatters by that time.

I, then Director of IPA, never made the admission attributed to me by Bednarik.

2. On 6 May 2002 the government announced the downgrading of IPA and CNART, which prompted the immediate resignation of the Director of IPA.

On Saturday, 4 May 2001, the media announced that the new government had decided that IPA was to be merged with IPPAR and, hence, that the single agency for the management of architectural and archaeological heritage that existed in Portugal until 1995 would be reinstated. On Monday, 6 May 2001, I requested confirmation from the Minister of Culture that these media reports were genuine. Having been informed that such was the case, I offered my resignation, which was accepted.

3. Many, if not most, archaeologists reacted to this along essentially political lines: IPPAR is seen as a creature of conservative politics, IPA as being a socialist structure.

In Portugal, the image of public archaeology is now so tarnished, because of its excesses between 1996 and 2002, that it will take many years of diligent work to recover public credibility.

The image and reputation of public archaeology in Portugal in 2001 and how archaeologists reacted to the new government's announcements can be evaluated from the contents of the forum created on IPA's website to discuss the merger. The forum was created on 8 May and shut down on 4 June on ministerial orders. On 22 May, after two weeks, statistics were posted. By then, the forum had received 152 messages from Portugal and 68 from abroad, for the most part from Portuguese archaeologists or foreign colleagues acquainted with IPA and archaeology in Portugal. 
If we bear in mind that APA (Associação Profissional de Arqueólogos, Portugal's association of professional archaeologists) has 254 members, the total for Portugal must be considered relevant in terms of the representation of the opinions of the profession. The messages posted until 22 May are also representative of the total forum, since only 38 more were posted after that. The statistics on the contents of the messages sent by nationals: 146 criticized the merger, 129 were complimentary about IPA's record of activity, only 12 were critical of IPA or of its Director. The statistics on the qualities seen by colleagues in IPA's activity: the most commonly cited were 'promotion of science in archaeology', 'commitment and professionalism of the staff' and 'efficiency in the preservation of archaeological heritage'.

Institutionally, the merger was further rejected by the professional associations, by university archaeologists and by archaeology students. Two demonstrations against the merger organized by the students were staged in Lisbon, in front of the Portuguese Parliament, on 14 May and 21 May 2001. Photos of these demonstrations were posted on the web forum.

Bednarik must be aware of these facts because he contributed to the forum.

4. The disgraced former Director of IPA argues that criticism of him 'serves to create confusion, and boosts a rejection of archaeology by the media and the public ...'

My words quoted by Bednarik refer to the unintended consequences of the manner in which IUPPS set up its Alqueva International Commission (cf. Zilhão, 2001b), not to the unintended consequences of criticism of me.

\section{ON BEDNARIK'S OMISSIONS}

In a paper intended to review recent developments in the public archaeology of Portugal and in which the Côa affair features so prominently, it is surprising that Bednarik makes no reference to his own involvement in it. In association with Alan Watchman, he solicited a consultancy contract with EDP in order to conduct the research that would prove them right on the view that the Côa art was only a few decades or centuries old. They did obtain that contract and their results, subsequently the object of extensive refutation (Zilhão, 1995;Dorn, 1996; 1997; Philips et al., 1997; Pope, 2000), were used by EDP, in the summer of 1995, to boost its strategy of discrediting archaeologists' efforts to stop the dam by disqualifying their scientific credentials. Bednarik himself generously contributed to that strategy. For instance, in statements published on 15 July 1995 on the front page of the weekly Expresso (the most influential newspaper in Portugal), he said that all Portuguese archaeologists and historians were 'incompetent' and that 'knowledge of archaeology and geomorphology in Portugal is very limited'.

The impact that the joint efforts of EDP and Bednarik had on the Portuguese public is easy to measure. Throughout the first half of 1995 , opinion polls indicated that a majority was in favour of stopping the dam to preserve the petroglyphs $(55 \%$ against $30 \%$ in June 1995 , according to a poll published in the weekly magazine Visão). The confusion created by the announcement of Bednarik and Watchman's results brought about a significant erosion of this support. In January 1996, a poll divulged in the Viva a Liberdade show of the national channel SIC (two months after the new government's decision to preserve the art and create the PAVC was announced) indicated that $28 \%$ were in favour of the decision, $39 \%$ were against, whereas the percentage of undecided had risen from the $15 \%$ in June 1995 to $33 \%$.

The very way in which Bednarik solicited his consultancy was the object of severe condemnation on ethical grounds, even within IFRAO. I quote from a 1996 editorial by the President of ARARA: 'Mr Bednarik has made numerous unscientific, misleading, and wrong statements about Côa, Portuguese archaeologists, and rock art researchers from around the world'; 'that statement [on the rationale presented to EDP to obtain the solicited consultancy] violates every tenet of a "professional code of ethics" whether in Australia or the USA' (Hyder, 1996). A motion censuring Bednarik for his actions in Côa in very strong terms was submitted to the 1996 IFRAO conference in Namibia (http:/ /rupestre.net/tracce/tr4sup.html).

Although Bednarik likes to present himself and his associates as the saviours of Côa, it is clear that, in fact, they acted as allies of the company building the dam that almost brought about the destruction of that art. These facts are widely known and acknowledged, and Bednarik's behaviour was censured even from within IFRAO. It is understandable that this turn of events must have deeply disturbed Bednarik and that there is no need to look further than simple psychology to obtain an explanation for his subsequent actions against the Côa Park, Portuguese archaeology and the Portuguese state. Since I was involved in the refutation of Bednarik's 'scientific' dating of the Côa art and in Portugal's efforts to preserve and effectively manage it for the public, the same explanation probably pertains with regard to his obsession with denigrating my person and my work through whatever means are available to him; I am perfectly willing to 'admit' that I deserve it.

\section{ON THE LAST QUARTER CENTURY OF PORTUGUESE PUBLIC ARCHAEOLOGY}

A brief overview of the history of Portuguese archaeology in the English language is provided in Zilhão (2001c). The country's archaeological record and archaeologists played an important role in mid 19 th century discussions of human origins, and investigation of megalithic monuments throughout the first half of the 20th century established Portugal as a major centre for the study of Neolithic funerary architecture. Until the late 1970s, however, most efforts and resources were dedicated to the study of Roman antiquities, 
and formal training in archaeology was provided within the framework of university departments of history. Teachers of archaeology in these universities were practically the only professionals operating in the country, with most activity being the product of the active commitment of numerous amateurs.

Over the last quarter century, the situation changed dramatically. Today, several hundred professionals exist, for the most part concentrated in the private sector or in municipal departments of cultural affairs; for instance, a recent inquiry into the latter by APA recorded 101 such departments employing 315 people, 193 of whom were archaeologists or archaeology technicians and illustrators (http://apa.no.sapo.pt/).

Urban archaeology and CRM in the framework of environmental impact assessment studies, mandatory in European Union law and enforced by Portugal's adherence to the Malta convention, were paramount factors in this expansion. State supervision of this activity focused on the issuing of permits for excavations, on the funding of research work, on the execution or inspection of salvage work and on the maintenance of the relevant, publicly available archives and databases. As the Côa affair made clear, however, the central administration lagged behind in the adoption of the management strategies and the employment of qualified personnel needed to adequately perform these tasks.

The Côa affair was a major turning point. The creation of IPA, in 1997, and the Alqueva salvage, which began the following year, represented a further boost. The APA enquiry mentioned above indicates that, of the 101 municipal departments surveyed, 21 had been created before 1985, 19 between 1985 and 1995, and 34 between 1995 and 2002; of the latter, $85 \%$ (29) were created after 1997. This reflects the country-wide operation of IPA's network of regional extensions, which, benefiting from the momentum created by the Côa story and from strong government backing, was able to obtain from developers practices of strict compliance with the law. In fact, it is IPA's effective activity as a regulatory authority that underpins the market demand for the services of archaeological consultancies behind the vibrant private sector observed by Tom Wheaton (see above).

IPA also created and maintained a journal (http:// www.ipa.min-cultura.pt/publicacoes/revista) and a monographic series (http://www.ipa.min-cultura.pt/publicacoes/ monog) for the scientific publication of research carried out in the country; these efforts have begun to effectively overcome one of the major shortcomings of Portuguese archaeology through the last quarter of a century. IPA's publications were made freely available as *.pdf files on its website, and access to them represented a significant portion of the traffic it generated. At the time of my resignation, this website had more visitors in a single day (an estimated 300 different individuals, based on the average daily figures of 40,000 hits, 1,000 pages served and $120 \mathrm{MB}$ of traffic, all figures exclusive of internally generated accesses) than most online versions of Portuguese daily newspapers had in a month; one-third of this traffic was initiated from nonPortuguese domains (IPA, 2002).

At the end of 1995, the weekly Expresso voted the Côa controversy the national political event of the year. In this framework, it is easy to understand how subsequent developments in Portugal's archaeology were inevitably politically high-profile. This was a major strength in that it allowed for swifter government action in legislation and administrative reform, but was at the same time a significant weakness, explaining to a large extent what happened after March 2002. When a right-wing coalition won the elections, the same political forces and, in fact, many of the same ministers who started the Côa dam project, were reinstated in power. Their behaviour over the Côa affair had alienated those political forces from the vast majority of the archaeological profession, with which, to this day, the current government maintains very few, if any, links. In my view, only this serious deficit in accessing competent, responsible advice can explain the erroneous decision to merge IPA and IPPAR.

It is still difficult to evaluate what consequences this merger will have for the future of public archaeology in Portugal. At the time of going to press (June 2004), IPA still exists, and the merger has not been consummated. In fact, two years after the decision was announced, the Ministry of Culture has yet to disclose the outline of the merging operation or the responsibilities and organogram of the single agency that is supposed to result from it.

\section{ON TOTALITARIANISM}

Bednarik's paper begins by describing Portugal as a country with 'a long history of totalitarian government', where 'procedures of popular dissent have a correspondingly short history'. By European standards, however, Portugal fares relatively well in any comparison along these lines (Birmingham, 1993). A liberal constitution was adopted in 1820, and Portugal has been a Republic since 1910, at a time when, in Europe, only Switzerland and France had democratically elected heads of state. Since 1820 , for some $60 \%$ of the time (the exceptions being a few years of interruption throughout the 19th century, and the long period of the SalazarCaetano dictatorship between 1926 and 1974), Portugal enjoyed a level of civil liberties and constitutional government similar to (if not higher than) that of most other European countries of today.

The relevance of past Portuguese history to the discussion of the record of the last ten years of the country's public archaeology is difficult to grasp. One possibility is that Bednarik wishes to secure a moral high ground with his readers even before presenting his case. This would make sense if he could claim to be part of a national tradition devoid of the original sins he sees in Portugal's, but that claim cannot be made, given that he is Austrian by birth and Australian by citizenship. Following Bednarik's logic, any 
exposé of those countries' archaeology and of his personal role in it would have to begin with a reference to Austria's responsibility, as part of the Third Reich, for the Holocaust. Where Australia is concerned, the concept of a long history does not apply, but one would have to bear in mind that the human rights crimes committed by Australia against its own people in the 20th century (such as the state-organized abduction of Aboriginal children) are arguably as bad as, if not far worse than, the denial of civil liberties and the crimes against political opponents which took place during the Salazar-Caetano dictatorship.

I have no wish to use the past history of Austria, Australia or any other country as an argument against Bednarik and his views, nor do I think that they are relevant to this controversy. Where Portugal is concerned, however, I 'admit' that Bednarik may, to a certain extent, have a point. On 25 April 1974, a revolution-i.e. a typical 'procedure of popular dissent'-put an end to one of the longest dictatorships of the 20th century and, at the same time, to the first and oldest world colonial empire. I was 17 years old at the time; young, certainly, but old enough to have been able to give my own very minor contribution, in words and deeds, to the simultaneous demise of that dictatorship and that empire. As such, I have had first-hand, direct experience of the arsenal used by totalitarian regimes to attack their opponents, among which fabricated events, forged admissions, falsified statements and anathema against dissenters feature prominently. It would be ironic indeed if Bednarik resorted to that same arsenal in his own writings about Portuguese archaeology, but that is a judgement best left to the reader.

\section{ACKNOWLEDGMENTS}

I am extremely grateful to Robert Bednarik and the Editor of Public Archaeology for providing the opportunity to set the record straight for a wider audience about the recent history of Portuguese archaeology. António Batarda, António Carlos Silva, António Martinho Baptista, António Monge Soares and Luís Luís carefully read the manuscript, verified the accuracy of the reported facts and provided several important details and sources. I thank Tom Wheaton for authorization to use his 2001 web posting and Bill Hyder for information on the 1996 IFRAO conference in Namibia. Any errors or omissions are my own.

João Zilhão

Contact address: Faculdade de Letras de Lisboa. Email: joao.zilhao@netcabo.pt

\section{REFERENCES}

Abreu, M.S. Alqueva - A descoberta das gravuras rupestre na margem portuguesa do rio Guadiana. Tracce 13 (2001a) (http://rupestre.net/tracce/13/alqueva.html).

Abreu, M.S. IFRAO report no. 26. Rock Art Research 18(1) (2001b) 68-69.

Abreu, M.S., Arcà, A., Parafita, A. Notes on the discovery of the Côa Valley rock art. Tracce 17 (2003) (http://

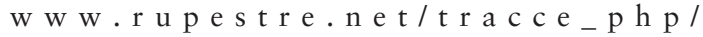
modules.php? name $=$ News\&file $=$ article $\&$ sid $=17$ ).

Andrade, J.S. Vila Nova de Fozcoa. In Cordeiro, J.A. (ed.) Anuário da Região Duriense. 1940. Régua, Imprensa do Douro (1940) 498-505.

Arcà, A., Bednarik, R.G., Fossati, A., Jaffe, L. and Simões de Abreu, M. Damned dams again: the plight of Portuguese rock art. Rock Art Research 18 (2001) i-iv.

Baptista, A.M. O complexo de gravuras rupestres do Vale da Casa (Vila Nova de Foz Côa). Arqueologia 8 (1983) 57-69.

Bednarik, R.G. Editorial. Rock Art Research 13(2) (1996) 83.

Bednarik, R.G. IFRAO report no. 29. Rock Art Research 19(2) (2002) 147-148

Birmingham, D. A Concise History of Portugal. Cambridge University Press, Cambridge (1993).

Cerrato, F. and Novillo, V. Los Petróglifos de la Ribera del Guadiana a su passo por las immediaciones de Cheles. Revista de Estudos Extremeños 56(1) (2000) 91-98.

Collado, H. Documentación y estudio de grabados rupestres en el entorno del Molino de Manzanez (Alconchel, Badajoz). Relatório técnico da $1^{\text {a }}$ fase. Manuscript on file at EDIA (2001).

Delgado Rodrigues, J. Conservação da Arte Rupestre do Parque Arqueológico do Vale do Côa. Relatório 241/99 - GERO. Manuscript on file at Instituto Português de Arqueologia (1999).

Dorn, R.I. A change of perception. La Pintura Fall (1996) 10-11.

Dorn, R.I. Constraining the age of the Côa Valley (Portugal) engravings with radiocarbon dating. Antiquity 71 (1997) 105-115.

García, M. and Luís, L. José Alcino Tomé e o último ciclo artístico rupestre do vale do Côa: um caso de Etnoarqueologia. Estudos Pré-Históricos 10 (2002) 199-223.

GTPC Nota Informativa 3/99. October (1999a).

GTPC Nota Informativa 4/99. December (1999b).

GTPC Nota Informativa 1/00. February (2000).

GTPC Nota Informativa 1/01. January (2001).

Guimarães, G. Arqueologia do Vale do Côa - a estação arqueológica da Quinta de Santa Maria da Ervamoira. In Jorge, V.O. (ed.) Dossier Côa. Sociedade Portuguesa de Antropologia e Etnologia, Porto (1995) 265-271.

Hyder, B. The President speaks. La Pintura (ARARA newsletter) Summer (1996).

Instituto Português de Arqueologia (IPA) 5 anos de actividade. Portfolio. Report submitted to the Government and Parliament of Portugal (2002).

International Union for Prehistoric and Protohistoric Sciences (IUPPS) International Union for Prehistoric and Protohistoric Sciences motion for the Guadiana rock art in Portugal. Rock Art Research 18(2) (2001) 131.

Jaffe, L. Systematic vandalism and improper conduct in the Côa valley rock art area. AURA Newsletter 13(2) (1996) 12-13. 
Lima, A.V. and Reis, M. Os públicos de Foz Côa. Cursos da Arrábida (1998) unpublished manuscript.

Lima, A.V. and Reis, M. O culto moderno dos monumentos. Os públicos do Parque Arqueológico do Vale do Côa. In Gonçalves, M.E. (ed.) O caso de Foz Côa: um laboratório de análise sociopolítica. Edições 70, Lisbon (2001) 145192.

Phillips, F.M., Flinsch, M., Elmore, D. and Sharma, P. Maximum ages of the Côa Valley (Portugal) engravings measured with chlorine-36. Antiquity 71 (1997) 100104.

Pope, G.A. Weathering of petroglyphs: direct assessment and implications for dating methods. Antiquity 74 (2000) 833-843.

Rebanda, N. Os trabalhos arqueológicos e o complexo de arte rupestre do Côa. Lisboa, Instituto Português do Património Arquitectónico e Arqueológico (1995).

Ribeiro, J.M.C. As gravuras não sabem nadar. Projecto Património, Queluz 2 (Julho) (1995) 39-41.

Romão, P. Colonização liquénica nas rochas xistosas do Parque Arqueológico do Vale do Côa. Manuscript on file at Instituto Português de Arqueologia (1999).

Sande Lemos, F. Arcaísmos na Arqueologia portuguesa. In Jorge, V.O. (ed.) Dossier Côa. Sociedade Portuguesa de Antropologia e Etnologia, Porto (1995) 463-466.

Serrão, E. da Cunha, Sande Lemos, F., Pinho Monteiro, J., Querol, M. de los Angeles, Rodrigues Lopes, S. and Oliveira Jorge, V. O complexo de arte rupestre do Tejo (Vila Nova de Rodão - Nisa). Noticia preliminar. Arqueologia e História 9(4) (1972) 349-397.

Stanley-Price, N. Conservation and management of prehistoric rock art sites on the World Heritage List. A report on the Côa Valley symposium, 1999. Conservation and Management of Archaeological Sites 4(1) (2000) 57-58.

Stanley-Price, N., Delgado Rodrigues, J., Prudêncio, M.I., Wyrwoll, T.W., Sullivan, S. and Padgett, A. Report of the International Commission on Conservation. Côa Valley Archaeological Park, Portugal. Manuscript on file at Instituto Português de Arqueologia (1997).
Swartz, B.K. An evaluation of rock art conservation practices at Foz Côa, northern Portugal. Rock Art Research 14 (1997a) 73-75.

Swartz, B.K. An investigation of the Portuguese government policies on the management of the Foz Côa sites. Rock Art Research 14 (1997b) 75-76.

Zilhão, J. The age of the Côa valley (Portugal) rock art: validation of archaeological dating to the Palaeolithic and refutation of scientific dating to historic or protohistoric times. Antiquity 69 (1995) 883-901.

Zilhão, J. (ed.) Arte Rupestre e Pré-história do Vale do Côa. Trabalhos de 1995-1996. Relatório científico ao governo da República Portuguesa elaborado nos termos da resolução do Conselho de Ministros $n^{\circ}$ 4/96, de 17 de Janeiro. Lisboa, Ministério da Cultura (1997).

Zilhão, J. The rock art of the Côa valley, Portugal. Significance, conservation and management. Conservation and Management of Archaeological Sites 2(4) (1998) 193-206.

Zilhão, J. Le Paléolithique supérieur du Portugal. Bilan quinquennal 1997-2001. In Union Internationale des Sciences Prehistoriques et Proto-Historiques, Commission VIII Le Paléolithique Supérieur Européen. Bilan Quinquennal 1996-2001. Liège, Études et Recherches Archéologiques de l'Université de Liège 97 (2001a) 161171.

Zilhão, J. The rock art of the Guadiana, the Alqueva dam, and the UISPP 'International Commission': a personal clarification. World Archaeological Bulletin 14 (2001b) 33-56.

Zilhão, J. Portugal. In Murray, T. (ed.) Encyclopedia of Archaeology. History and Discoveries. ABC-Clio, Santa Barbara, 3 (2001c) 1062-1071.

Zilhão, J. and Baptista, A.M. Reply by Instituto Português de Arqueologia to CAR-ICOMOS Alqueva report. World Archaeological Bulletin 14 (2001) 23-32.

Zilhão, J., Aubry, Th., Carvalho, A.F., Baptista, A.M., Gomes, M.V. and Meireles, J. The rock art of the Côa Valley (Portugal) and its archaeological context. Journal of European Archaeology 5(1) (1997) 7-49. 


\section{APPENDIX}

Letter from J. Zilhão to Shirley Ann Pager, IFRAO 1996 President, Southern African Rock Art Research Association, PO Box 1285, Okahandja, Namibia

Lisboa, August 26, 1996.

Dear Colleague;

On August 10,1996, the Archaeological Park of the Côa Valley was officially opened. This event was a great success and the public has responded with a large turnout. Commentators in the national and international media were unanimous in expressing the opinion that this success represented the point of no return in the process of abandonment of the Foz Côa dam project and preservation of the Côa Valley petroglyph sites.

Two days later, on August 12, Ludwig Jaffe, writing on behalf of IFRAO, posted an appeal on the Internet where my Portuguese colleagues working in the Côa Valley and I were accused of 'systemtaic professional vandalism'. Similar accusations were voiced by Mila Simões de Abreu, in a letter to the head of the Instituto Português de Arqueologia, dated August 14. Jaffe explicitly questioned my position as leader of the Park project and demanded my resignation ('João Zilhão proved that he is not capable of protecting the rock art of the Côa Valley and he cannot be left in charge of this fine and delicate heritage').

On August 27, the widely-read Portuguese newspaper Expresso ran the following headline: 'American expert says that [Côa Valley ] petroglyphs are being destroyed'. The American in question was Jane Kolber, who was reported to have alerted her American colleagues to the fact that the recording presently in progress in the best major sites in the Côa was using 'damaging intrusive methods such as cleaning and removing lichen'.

Apparently Kolber formed this opinion during her July stay in Portugal as part of a team led by Abreu doing recording work in a different part of the rock art complex of the Côa. Although working under a permit granted by the Portuguese authorities, this team did not communicate with the Park coordinator until August 23, when Jane Kolber asked for a meeting. All these accusations were publicised on the Internet, in the newspapers and to colleagues before the matter was presented to the Park coordinator.

Whether lichen should or should not be removed from rocks and how to go about doing it is a matter for scientific debate. Jaffe and Kolber are entirely in their right to believe that it should never be done, as others are in their right to believe that such a fundamentalist point of view is inadequate and contradictory with the need for adequate study and presentation of the panels to the public.
It is precisely because we are aware that this is a difficult issue that, last May, we have asked our consultant, Dr Nicholas Stanley-Price, to organise an international mission of conservation experts to come to the Côa in 1997. Dealing with lichen is but one of the serious problems we have. The others are, for instance, the effect of periodic inundation on some sites, the need to consolidate some rock masses bearing engravings, the disguising of recent graffiti on surfaces adjacent to some decorated panels, or the consequences that might arise from the re-exposure of some now submerged sites.

In a report dated February 11, submitted to us after his first visit to the Côa sites, when the matter was the subject of some discussion, Dr Stanley-Price explicitly mentioned among the technical conservation measures possibly to be adopted in a future management plan 'the limited removal of lichen and other surface deposits to facilitate the reading of some panels'. The issue was also discussed with rock art experts who visited the Côa in the spring of 1996, such as Dominique Sacchi, Denis Vialou and Francesco d'Errico. None was of the opinion that lichen should not be removed. Instead, all were of the opinion that lichen should be removed and that we should study the best ways of doing it without causing damage to the rock surfaces.

The political need to open the Park in the summer of 1996 made it necessary to undertake a certain amount of recording and, therefore, of lichen cleaning, before the arrival of the international conservation mission we had asked Dr Stanley-Price to organise. Such cleaning was done mechanically, with wooden tools and using river water. Only the softer and most superficial lichen was removed and in only some of the panels. Most of them, anyway, had very little lichen cover to begin with (as you may remember, the limited extent of lichen cover was one of the arguments put forward by some to question the Palaeolithic age of the Côa rock art).

I assume full responsibility for the decision to allow my colleagues doing the rock art recording to perform this cleaning. I followed their work, which was made with great care and I believe that no damage was made to the surfaces. Also, the possibility of using dating methods such as those applied in the Côa in 1995 by Ronald Dorn, Fred Philips and Alan Watchman is in no way harmed by the lichen cleaning undertaken by our recording team.

In her conversation with me, Jane Kolber also mentioned that she objected to the archaeological excavations that we made next to the rock panels. I explained to her that I was unable to understand how such an objection could even be raised, since it has always been a standard procedure in European rock art research to undertake excavations as a means towards the collection of archaeological and geological information of relevance to the study of the art.

The accusations of 'professional vandalism' put forward by Abreu and Jaffe, following what IFRAO convener Robert Bednarik has been doing for more than a year now, are entirely unfounded. However, I am willing to submit the work carried out in the Côa to a formal investigation by any 
international commission of recognised experts. In a letter previously sent to four prominent IFRAO members who are well acquainted with the situation because they were in the valley in 1995 - Paul Bahn, Ben Swartz, Andrea Arcà and Angelo Fossati-I suggested that they should be included in such a commission. Andrea Arcà and Angelo Fossati have subsequently replied that, being involved, they had to decline and suggested that I contact you.

Thus, as a professional whose honour and ethics have been questioned, I formally commit myself before you, as IFRAO 1996 President, to stand the judgement of colleagues. I invite you to send an IFRAO delegation to the Côa and commit myself to give that delegation access to all documents in our possession (photos, slides, tracings, etc.) that can be of use in assessing whether any damage was inflicted to the art, as Abreu and Jaffe claim was the case.

I also want to make it clear that throughout my entire life I have been educated in making a distinction between accusations of making a mistake, which is a normal thing for any human being to make, and accusations of practices that lie outside the ethics of a profession. The accusations of systematic vandalism that Abreu, Jaffe and Bednarik have been making against Portuguese archaeologists belong to the second category, are of a moral nature, and therefore should be taken very seriously. Such accusations have been voiced in their capacity of IFRAO representatives. I believe, therefore, that IFRAO has the obligation to act, either by sending an investigative commission if it finds the accusations to be credible, or by apologising to the accused and disavowing Abreu, Bednarik and Jaffe's use of IFRAO to back their actions.
I am also letting you know that I am complaining against Abreu and Jaffe to the Associação dos Arqueólogos Portugueses and the Associação Profissional de Arqueólogos. I will ask these associations to investigate their accusations and to take action against them for their systematic use of insult and slander against colleagues.

\section{Yours sincerely,}

João Zilhão.

Professor, Department of History, Faculdade de Letras de Lisboa.

Project Coordinator, Côa Valley Archaeological Park.

\section{EDITOR'S NOTE}

In view of the intensity of this discussion, and its particular importance to the two individuals involved, Public Archaeology intends to host a second exchange in the next issue of the journal, led by a response from Robert Bednarik. Constraints of space prevent the inclusion of further contributions from the protagonists in this issue.

For each of them, there remains a need to challenge some of the evidence and interpretations produced by the other. The point of publishing these exchanges is that their original subject, the handling of the rock art of the Côa and Guadiana valleys, became one of the most significant of recent confrontations between government, archaeology and the public interest in conservation. This battlefield needs to be cleared of gunsmoke and properly understood. 